OECD Environment Working Papers No. 63

\title{
The Political Economy of British Columbia's Carbon \\ Tax
}

Kathryn Harrison 
Organisation de Coopération et de Développement Économiques

Organisation for Economic Co-operation and Development

08-Oct-2013

ENVIRONMENT DIRECTORATE

English - Or. English

ENVIRONMENT WORKING PAPER No.63 - THE POLITICAL ECONOMY OF BRITISH COLUMBIA'S CARBON TAX

By Prof. Kathryn Harrison (1)

(1) University of British Columbia.

JEL Classification: F18, H23, P48, Q5, Q38, Q48, Q58.

Keywords: Carbon tax, Political economy, Policy lessons.

OECD Environment Working Papers are available at www.oecd.org/env/workingpapers.htm

JT03345839

Complete document available on OLIS in its original format

This document and any map included herein are without prejudice to the status of or sovereignty over any territory, to the delimitation of international frontiers and boundaries and to the name of any territory, city or area. 


\section{OECD ENVIRONMENT WORKING PAPERS}

This series is designed to make available to a wider readership selected studies on environmental issues prepared for use within the OECD. Authorship is usually collective, but principal authors are named.

The papers are generally available only in their original language English or French with a summary in the other if available.

The opinions expressed in these papers are the sole responsibility of the author(s) and do not necessarily reflect those of the OECD or the governments of its member countries.

Comment on the series is welcome, and should be sent to either env.contact@oecd.org or the Environment Directorate, 2, rue André Pascal, 75775 PARIS CEDEX 16, France.

OECD Environment Working Papers are published on www.oecd.org/env/workingpapers.htm

Applications for permission to reproduce or translate all or part of this material should be made to:

OECD Publishing, rights@oecd.org or by fax 33145249930.

COPYRIGHT OECD 2013 
ENV/WKP(2013)10

\begin{abstract}
In July 2008, the Canadian province of British Columbia (BC) launched North America's first revenue-neutral carbon tax reform. The tax, which applied to all combustion sources of all fossil fuels, was introduced at a rate of CAD 10 per tonne of $\mathrm{CO}_{2}$, with a schedule for annual increases of CAD 5 per tonne of $\mathrm{CO}_{2}$ until the tax reached CAD 30 per tonne of $\mathrm{CO}_{2}$ in 2012. Tax revenues were fully recycled via a combination of corporate and income tax cuts, phased in over time. This paper reviews the political economy of the $\mathrm{BC}$ tax in three distinct periods - its origins, its survival in the face of political backlash, and its longer-term prospects.

The emergence of a carbon tax in British Columbia reflected a confluence of political conditions ripe for carbon taxation: availability of untapped hydro potential, a surge in public concern for climate change, a committed leader with the institutional capacity to pursue his personal policy preferences, and a right-ofcentre government with the trust of the business community. While public concern justified some degree of policy reform, the decision to pursue an efficient, but potentially controversial, carbon tax was made by the Premier himself. However, with input from the business community, the Liberal government managed to craft a broad-based and revenue-neutral tax that did not provoke significant business objections.

The tax did provoke public opposition, however. Popular perceptions of the tax as unfair, which emerged initially in rural communities, were reinforced and extended by the opposition New Democratic Party via a populist "Axe the Tax" campaign. However, despite a surge in public opposition to the tax, and a corresponding decline in support for the governing party, the Liberal government, and thus its carbon tax, managed to survive an election the following year. The outcome arguably had little to do with the carbon tax, but is explained, rather, by a resurgence of voter support for the Liberals in response to the intervening global recession.

Five years later, the $\mathrm{BC}$ experience suggests that the political economy of an established carbon tax is very different from that of a new one. Public support has rebounded, with the fraction of voters supporting the tax now almost double the fraction opposed. Although business opposition emerged as the tax was gradually increased and as other North American jurisdictions failed to follow through on their commitments to carbon pricing, that opposition has been constrained by two factors. Academic studies are beginning to emerge suggesting that the tax has prompted greenhouse gas emissions reductions without significant harm to the economy. In addition, the $\mathrm{BC}$ government has become increasingly reliant on carbon tax revenues during a period of limited economic growth. In effect, as public attention has subsided, it has become easier to keep the existing tax than to risk renewed public ire by replacing it. That said, the provincial government has committed to freeze the tax rate at CAD 30 per tonne for five years, and likely will face continuing political pressure for exemptions from trade-exposed industries. It is critical that any concessions be based on sound analysis and clear principles rather than political leverage, and also carefully designed to maintain an effective carbon price signal. Experience with concessions granted to date to local governments, rural voters, and farmers provide cause for concern in that regard.
\end{abstract}

JEL Classification: F18, H23, P48, Q5, Q38, Q48, Q58.

Keywords: Carbon tax, Political economy, Policy lessons. 


\section{RÉSUMÉ}

En juillet 2008, la province canadienne de Colombie-Britannique a été la première collectivité d'Amérique du Nord à procéder à une réforme fiscale sans incidence sur les recettes impliquant la mise en place d'une taxe carbone. Le montant de cette taxe frappant l'ensemble des sources de combustion et des énergies fossiles a été fixé dans un premier temps à $10 \mathrm{CAD}$ par tonne de $\mathrm{CO}_{2}$, mais il était prévu dès le départ qu'il augmenterait chaque année de $5 \mathrm{CAD}$ pour atteindre $30 \mathrm{CAD}$ par tonne de $\mathrm{CO}_{2}$ en 2012. Le produit de la taxe carbone a été intégralement recyclé sous forme de baisses progressives de l'impôt sur les sociétés et de l'impôt sur le revenu. Le présent document examine l'économie politique de la taxe instaurée par la Colombie-Britannique en distinguant trois phases : les origines de la taxe, son maintien sur fond de réactions politiques négatives et ses perspectives à plus long terme.

Si une taxe carbone a vu le jour en Colombie-Britannique, c'est parce que plusieurs conditions favorables étaient réunies à ce moment-là : l'existence d'un potentiel hydroélectrique non encore exploité, une opinion publique très préoccupée par le changement climatique, un dirigeant déterminé disposant des capacités institutionnelles voulues pour faire prévaloir sa ligne d'action et la présence au pouvoir d'un gouvernement de centre-droit ayant la confiance des milieux d'affaires. Si les préoccupations des citoyens justifiaient de réformer jusqu'à un certain point les politiques en vigueur, c'est le Premier ministre luimême qui a pris la décision de créer une taxe carbone qui était certes efficiente, mais qui avait de fortes chances d'être controversée. Avec le concours des milieux économiques, le gouvernement libéral a réussi à concevoir une taxe à large assiette et sans incidence sur les recettes qui n'a pas suscité d'objections significatives parmi les entreprises.

En revanche, elle a provoqué des réactions de rejet et un sentiment d'injustice dans l'opinion publique. Parti des campagnes, ce sentiment a été renforcé et a gagné de larges pans de l'opinion publique à la suite de la campagne populaire menée par le Nouveau Parti démocratique, formation d'opposition, sur le thème «Axe the Tax » (« supprimez la taxe »). Cependant, malgré un fort courant hostile et la baisse du parti au pouvoir dans les sondages d'opinion, le gouvernement libéral est sorti vainqueur des élections organisées l'année suivante et la taxe a donc été maintenue. Ce résultat électoral n'avait sans doute pas grand-chose à voir avec la taxe carbone, mais s'explique plutôt par le retour en grâce du Parti libéral auprès des électeurs en réaction à la récession mondiale qui s'était alors déclarée.

Avec cinq ans de recul, l'expérience menée en Colombie-Britannique semble indiquer que l'économie politique d'une taxe carbone en place est très différente de celle d'une nouvelle. Entretemps, l'opinion publique s'est retournée, puisque les électeurs favorables à la taxe sont désormais presque deux fois plus nombreux que ceux qui y sont opposés. Même si un courant hostile est apparu parmi les entreprises à mesure que le montant de la taxe était relevé et que d'autres collectivités nord-américaines reniaient dans les faits leurs engagements de tarification du carbone, cette opposition a été limitée par deux facteurs : d'une part, la publication récente d'études universitaires tendant à démontrer que la taxe carbone a fait baisser les émissions de gaz à effet de serre sans causer de préjudice significatif à l'économie et, d'autre part, le fait que le gouvernement de Colombie-Britannique est de plus en plus tributaire de ses recettes en période de croissance économique atone. En fait, l'opinion publique n'étant plus désormais focalisée sur la taxe carbone, il est plus simple de la conserver que de tenter de la remplacer par un autre dispositif qui risque de déclencher à nouveau une vague de rejet. Cela étant, le gouvernement provincial s'est engagé à maintenir le montant de la taxe à $30 \mathrm{CAD}$ par tonne de $\mathrm{CO}_{2}$ pendant cinq ans, et il continuera sans doute de subir les pressions des secteurs exposés aux échanges internationaux qui souhaitent en être exonérés. Il est 
essentiel que toute éventuelle concession soit décidée sur la base d'une analyse rationnelle et de principes clairs plutôt qu'en fonction de l'influence politique des différents secteurs, et qu'elle soit en outre conçue avec soin pour préserver l'effectivité du signal de prix du carbone. Or le bilan des concessions accordées jusqu'à présent aux administrations locales, aux électeurs ruraux et aux agriculteurs n'incite pas forcément à l'optimisme de ce point de vue.

Classification JEL : F18, H23, P48, Q5, Q38, Q48, Q58.

Mots-clés : Taxe carbone, Économie politique, Enseignements pour l'action gouvernementale. 


\section{FOREWORD}

This paper was written by Prof. Kathryn Harrison of the University of British Columbia. It discusses the political economy of the carbon tax applied in British Columbia, Canada, and it contributes to two ongoing projects at the OECD:

- A project on lessons on environmental policy reform, under the auspices of the Working Party on Integrating Environment and Economic Policies; and

- A project on the political economy of environmental taxation, under the auspices of the Joint Meetings of Tax and Environment Experts.

This work is published on the responsibility of the Secretary-General of the OECD. The opinions expressed and arguments employed herein do not necessarily reflect the official views of the Organisation or of the government of its member countries. 
TABLE OF CONTENTS

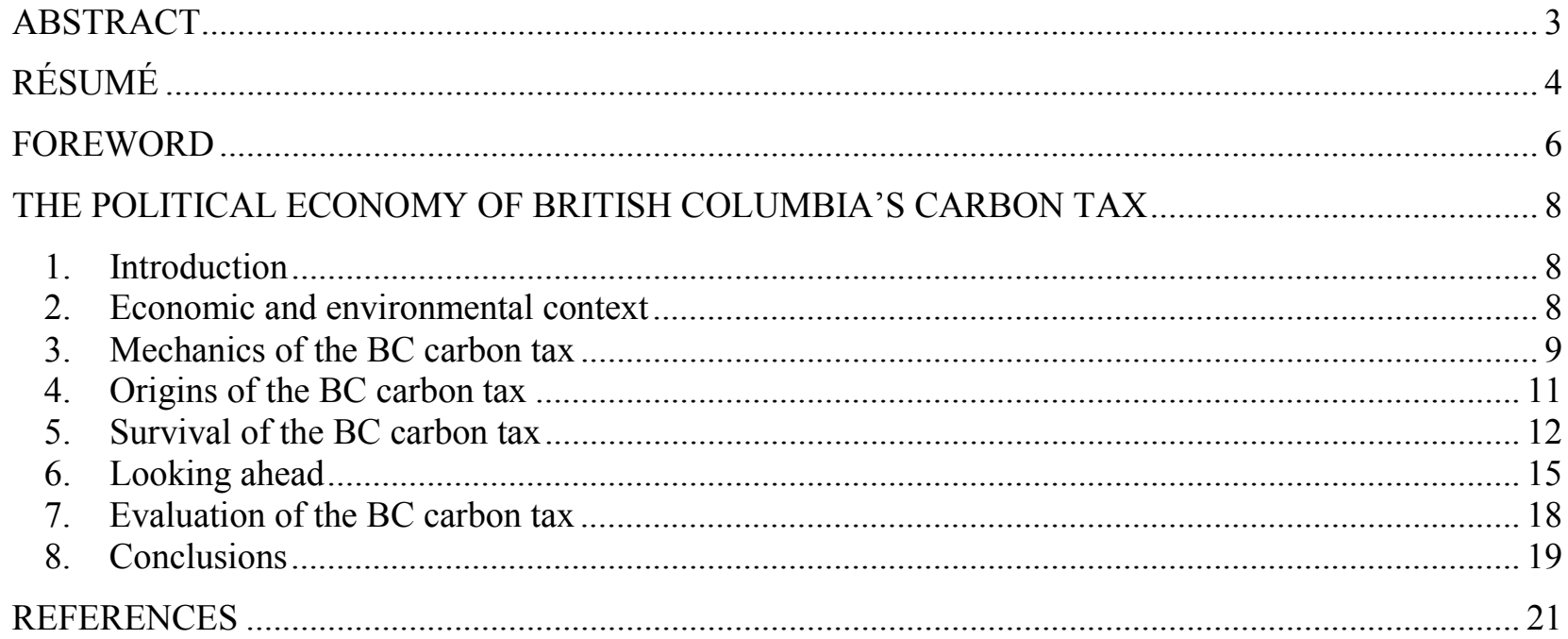

\section{Figures}

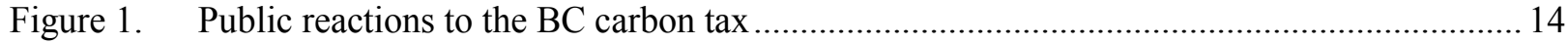

Figure 2. Trends in British Columbians' priorities ....................................................................... 15

Figure 3. Sales of petroleum fuels subject to British Columbia's carbon tax ................................... 18 


\section{THE POLITICAL ECONOMY OF BRITISH COLUMBIA'S CARBON TAX}

\section{Introduction}

1. In July 2008, the Canadian province of British Columbia (BC) launched North America's first revenue-neutral carbon tax reform. The tax was introduced at a rate of CAD 10 per tonne $\mathrm{CO}_{2}$, with a schedule for annual increases of CAD 5 per tonne $\mathrm{CO}_{2}$ until the tax reached CAD 30 per tonne $\mathrm{CO}_{2}$ in 2012. The BC tax stands apart from most other carbon taxes globally in applying equally to all combustion sources of all fossil fuels within the province (Ciocirlan \& Yandle, 2003; Harrison, 2010). Many observers were surprised that a right-of-centre government not known for its environmentalism would embrace a carbon tax at all, let alone a textbook example that applied to all fuels and sectors, even as other governments in North America were opting for the more "incumbent friendly" solution of cap and trade (Baldwin 2008).

\section{Economic and environmental context}

2. Canada is among the most emissions-intensive countries in the OECD, with per capita emissions in 2010 of $20.3 \mathrm{~kg}$ of $\mathrm{CO}_{2}$ eq per year. ${ }^{1}$ Those emissions reflect Canada's reliance on ample fossil fuel endowments for both domestic use and net exports of carbon-intensive manufactured goods and fossil fuels (Davis et al., 2011). There are, however, pronounced differences in the carbon-intensity of the ten Canadian provinces. At the limits, hydropower-rich Quebec has per capita emissions of $10 \mathrm{~kg}$ of $\mathrm{CO}_{2} \mathrm{eq}$ per year while Saskatchewan and Alberta, which both produce oil and gas for export and rely on coal for electricity, have per capita emissions seven times greater. Not coincidentally, the provinces with the lowest per capita emissions, reflecting abundant hydroelectric potential, have been the most active in addressing climate change, while those with the highest per capita emissions have been most resistant (Harrison, 2013).

3. British Columbia's second-lowest per capita emissions among Canadian provinces of $12.4 \mathrm{~kg}$ of $\mathrm{CO}_{2}$ eq per year reflect the mountainous jurisdiction's access to abundant hydro-power, which accounts for $93 \%$ of its electricity generation. In the absence of fossil fuel power plants and with other industrial sources heavily reliant on hydroelectricity, stationary sources account for just $37 \%$ of BC's emissions compared to $54 \%$ nationally. The province's significant forest products industry also has relatively low greenhouse gas emissions. However, with less emissions-intensive point sources, transportation accounts for a proportionately larger share of BC's greenhouse gas emissions, at $38 \%$ compared to $28 \%$ nationally. BC's greenhouse gas emissions increased by 12\% between 1990 and 2010 (British Columbia 2012a), while the provincial population increased by $40 \%$ over the same period. The transportation sector accounted for just over half of the emissions increase, while industrial combustion emissions were fairly stable.

4. Although it has taken advantage of its clean energy endowments, BC does have economically significant greenhouse gas-intensive industries, most notably cement, aluminium, mining, and, increasingly, natural gas production. The political influence of those sectors also tends to be reinforced by their location in economically dependent rural communities. Paradoxically, although BC's coal industry

1. All emissions data are from Canada (2010), while population figures are as reported by Statistics Canada. 
accounts for $80 \%$ of Canada's coal production by value $)^{2}$ and competes with forest products as BC's top export, it does not pose a significant problem for BC's own climate targets because almost all of BC's coal is shipped to other jurisdictions. The province's rapidly growing natural gas sector is another matter. Fugitive and venting emissions accounted for one quarter of provincial emissions growth between 1990 and 2010 (British Columbia, 2012a). Rapidly expanding production from emissions-intensive "fracking" of shale reservoirs and operation of energy-intensive liquefied national gas export terminals, several of which are proposed on the $\mathrm{BC}$ coast, will together present a tremendous challenge to $\mathrm{BC}$ 's greenhouse gas reduction targets.

5. The same mountainous terrain that has given rise to BC's relatively low-carbon economy also has given rise to a strong wilderness-oriented environmental movement. That is something of a mixed blessing for BC climate policy, however. On the one hand, a well-organized local environmental community strongly supports action on climate change. On the other hand, there is significant political opposition among $\mathrm{BC}$ environmentalists to new hydro-power developments that threaten BC's wilderness.

\section{Mechanics of the $\mathrm{BC}$ carbon tax}

6. The BC carbon tax was announced in February 2008 and took effect on July 1 of that year. The tax was introduced at a relatively low rate of CAD 10 per tonne of $\mathrm{CO}_{2 \text { eq }}$, but with a schedule of four annual CAD 5 per tonne increases until it reached CAD 30 per tonne in July 2012. To place the carbon tax in perspective, in July 2012, it contributed CAD 0.067 to the typical price of CAD 1.40 for a litre of gasoline in Vancouver. Other federal, provincial, and local excise and sales taxes contributed an additional CAD 0.40 (Natural Resources Canada, 2012). Neither the magnitude of the carbon tax, nor that of other taxes, is made explicit to motor fuel consumers at the point of purchase, though at least one natural gas provider does specify the contribution of the carbon tax in households' monthly bills.

7. The carbon tax applies to all greenhouse gases emitted by all sources of combustion of all fossil fuels (plus peat and used tires where used for heat or energy). The carbon tax does not cover all sources of greenhouse gas emissions within BC, however. Non-combustion emissions from industrial processes, such as cement production, and venting and fugitive emissions (e.g., from natural gas production and landfills) are not covered, though combustion emissions from those same sectors are subject to the tax. When it was introduced in 2008, the carbon tax applied to $77 \%$ of BC's greenhouse gas emissions, but that has fallen to $70 \%$ in 2012 with a significant increase in non-combustion emissions from growing natural gas production.

8. The carbon tax is charged to the consumer at the point of final sale, but passed back via the retailer to the wholesaler, who is responsible for conveying the tax revenue to the province. Administration of the new tax is relatively straightforward because it is collected at the same time as pre-existing taxes (e.g., the provincial excise tax on motor fuels). No provisions have been made to date to tax imported goods based on production emissions, nor to reimburse $\mathrm{BC}$ manufacturers for carbon taxes paid on goods that they export. However, exported fossil fuels and sales of marine and aviation fuels that will produce emissions outside the province are exempt.

9. In establishing the carbon tax, the provincial government made a binding legislative commitment to return all carbon tax revenues to individuals and firms via corresponding tax cuts. Indeed, the enacting legislation threatens to reduce the Finance Minister's salary by $15 \%$ should she or he fail to do so. Interestingly, revenue-neutrality is defined as having tax cuts of value equal to or greater than carbon tax revenues. In practice, the tax reform has in fact been revenue-negative: the province gave back more money in tax cuts than it collected in each of the first 5 years. This is perhaps not surprising since the threat to the Minister's salary creates an incentive to err on the side of tax cuts, though it is also the case that

2. Statistics Canada table 379-0025. Data for 2010. 
carbon tax revenues have been lower than anticipated. In 2012-13, during which the tax reached its scheduled maximum of CAD 30 per tonne, the province projected annual revenues of CAD 1.2 billion and tax expenditures of CAD 1.3 billion, roughly $3 \%$ of its CAD 43 billion budget (British Columbia, 2012b).

10. The initial tax cuts announced in 2008 included a $5 \%$ reduction over two years in the individual income tax rate for the first two tax brackets (those earning less than about CAD 70,000 per year). In recognition of regressiveness of an energy tax, a low-income tax credit also was included. With a fixed value of CAD 100 per adult and CAD 30 per child, the low-income tax credit took the form of a lump sum payment, albeit contingent on adults' completion of a tax return. The general corporate income tax rate was reduced from 12 to $10 \%$ over two years, while the small business rate was reduced from 4.5 to $2.5 \%$ over three years. A one-time Climate Action Dividend of CAD 100 per adult also was provided in 2008, in the form of a direct payment rather than tax deduction.

11. Several other features of the tax cuts are noteworthy. First, corporate tax cuts were phased in more gradually than tax cuts for individuals, and were proportionately deeper relative to a lower initial corporate tax rate. Thus, two thirds of tax cuts initially went to individuals and one third to firms, even though the opposite proportion applied to tax revenues. Over time, however, the ratio shifted, and more than half of tax cuts now flow to the business community. Second, as increases in the tax have necessitated further cuts to achieve revenue neutrality beyond those initially announced for the first three years, the list of new tax expenditures has included increasingly specific and, in some cases, seemingly unrelated tax credits. An industrial property tax credit and Northern and Rural Homeowner Benefit were added in the 2009 budget, while 2012 additions included business tax credits for video game production, film production, and scientific research, and individual tax credits for children's fitness and seniors' home renovations. At least some of these tax credits existed prior to 2012. This suggests that should further carbon tax increases be pursued over time, revenue-neutrality could become little more than a shell game, in which the provincial government fulfils its commitment to recycle revenues not by reducing taxes but, rather, by shifting existing tax expenditures to the carbon tax ledger. The shift from adjustments in broad tax rates to specific tax credits also represents an evolution from recycling tax revenues to the same people who pay the carbon tax to redirecting revenues from carbon taxpayers to more specific, and presumably more attentive, subpopulations.

12. The BC carbon tax was one of many provincial climate policies introduced in 2007 and 2008, two of which were entwined with the tax. In 2007, the provincial government committed to participation in economy-wide emissions trading with four other provinces and seven US states as part of the Western Climate Initiative. Although it remained to be determined how the fixed-price carbon tax would be reconciled with a concurrent floating-price trading regime, the latter initially was expected to control noncombustion sources that were not covered from the carbon tax.

13. The province also committed to "carbon-neutral government" by 2010. Public sector organisations within provincial jurisdiction, including provincial ministries, public schools, universities, Crown corporations and hospitals, were mandated to purchase carbon offsets at a rate of CAD 25 per tonne from a newly established Pacific Carbon Trust. The Pacific Carbon Trust is directed to purchase emissions offsets only within British Columbia. Although the carbon tax and carbon-neutral government policies are distinct, their combined effect was that public sector organisations would be required to pay roughly double for their carbon emissions, once via the carbon tax on fuel purchases and once to purchase offsets on resulting emissions, and to do so without benefit of the corresponding income tax cuts provided to the private sector. 


\section{Origins of the $\mathrm{BC}$ carbon tax}

14. British Columbia's emergence as a climate policy leader in 2007 came as a surprise to most observers. The Liberal government led by Premier Gordon Campbell had been reviled by environmentalists for cuts to the province's environment budget and support for offshore oil and gas exploration and proposed new coal-fired electricity-generating stations. The BC government's adoption of a carbon tax, at a time when other North American governments were embracing cap and trade, also was a surprise. Carbon taxes have several political disadvantages relative to emissions trading (Harrison, 2010, 2012). From business' perspective, cap and trade offers the prospect of windfall gains from free allocation of permits, which have no counterpart under a carbon tax regime. From voters' perspective, the costs of a carbon tax are more visible than those indirectly passed on to consumers under a trading regime. This visibility is compounded the psychological phenomenon of loss aversion (Kahneman, Knetsch, \& Thaler, 1991), which suggests that voters' appreciation of any resulting tax deductions is unlikely to match their resentment of new taxes, even when the two are of the same magnitude.

15. Against this backdrop, the origins of British Columbia carbon tax are explained by the confluence of five factors. First, as noted above, BC was in an enviable position to draw on hydropower resources to reduce its emissions, thus making it easier for the province to set demanding climate action goals. The second factor was a Canada-wide surge in voters' attention to climate change. For more than two decades Canadians have expressed concern when asked about climate change; however, the issue has seldom been "top-of-mind" with voters. That changed over the course of 2006, when the proportion of Canadians who identified the environment as the single "most important problem" facing Canada surged from single digits to over $20 \%$, at which point it was the single most frequently cited issue.

16. Canadian federal and provincial governments alike responded to voters' newfound enthusiasm for climate change with a flurry of policy announcements. The BC government's climate policy agenda, unveiled in February 2007, included commitments to reduce the province's emissions by $33 \%$ (10\% below 1990) by 2020, to match California's tailpipe standards for motor vehicles, that at least $90 \%$ of electricity consumed in the province would be derived from renewable sources, and that new and existing electricity production within $\mathrm{BC}$ would have net zero emissions by 2016. The last of these commitments had the effect of forcing the public electric utility, BC Hydro, to cancel planned coal-fired and co-generation plants (Rhodes and Jaccard, 2013). Within months, BC also announced that it would join five US states in development of the Western Climate Initiative's cap and trade program.

17. Public attention to climate change and access to renewable energy were not sufficient, however, to prompt a carbon tax in the 2007 package of climate policy measures. A third factor that contributed to adoption of the carbon tax is the existence of a right-of-centre majority government when climate change surged in prominence. British Columbia has a two-party system with the self-proclaimed "free enterprise" Liberal Party on the right and the social-democratic New Democratic Party (NDP) on the left. With no risk of a competitor stealing votes from the right at the time, climate change offered an appealing opportunity for the Liberals to steal centrist votes from the NDP. Perhaps even more important, the business community was arguably willing to grant greater leeway to a Liberal government than it would have been to an NDP government.

18. The environmental community, although historically more closely affiliated with the NDP, was supportive of the provincial government's new climate announcements, but urged the province to go further and include a carbon tax in the 2008 budget (Harrison, 2012). The academic community also voiced support for a carbon tax via editorials in the province's newspapers (Mather, Olewiler \& Elgie, 2007; Jaccard, 2007) and an open letter signed by 70 economics professors from BC's major research universities (Green, 2007). More striking than expressions of support for a carbon tax from predictable sources, though, was the absence of any backlash from the BC business community. The business 
community had been stunned by province's new climate policy agenda in early 2007 (Harrison 2012). However, faced with unprecedented public attention to climate change, and resulting investor anxiety, by year-end the business community acknowledged the need for some form of carbon pricing (Belfry, 2010). In that context, business leaders expressed cautious support for a carbon tax when approached privately by the Premier's office. The business community's support was contingent on two conditions, though, both of which were subsequently met by the provincial government: that the tax reform be revenue neutral, and that the tax be applied evenly to households and industrial sources (Peet and Harrison, 2012). From business' perspective, a carbon tax provided a mechanism to share the burden for meeting the province's ambitious emissions targets with households and the transportation sector, which was particularly important in BC given industry's relatively low share of provincial emissions.

19. Despite public support for generic actions to address climate change, the provincial government anticipated that a new tax could generate backlash among voters. By the time of the spring 2008 budget, the environment also had begun its fall from the top of the polls. Given the timing, a critical fourth factor in accounting for the government's decision to move forward with a potentially controversial carbon tax was the strong personal commitment of Premier Gordon Campbell. In 2006 and 2007, the Premier had undertaken extensive reading on climate change, and engaged in several conservations on the subject with his California counterpart, Governor Arnold Schwarzenegger (Harrison 2012). In response, the Premier created a Cabinet committee on climate action, which he personally chaired, and established a Climate Action Secretariat within his office. A closely related fifth factor that facilitated BC's adoption of a carbon tax is political institutions. The combination of parliamentary government and a single member plurality electoral system tends to concentrate authority in a small number of hands, most notably those of the leader of a party that holds a majority of seats in the legislature. Premier Gordon Campbell thus was not only willing but able to personally make the call to adopt a revenue-neutral carbon tax in British Columbia.

\section{Survival of the BC carbon tax}

20. Initial reaction to the carbon tax was positive. Academics were enthusiastic. BC's major environmental groups offered an unprecedented show of support for a government that previously had few friends in the environmental community (David Suzuki Foundation, 2008a). Even the business community was cautiously supportive (Vancouver Board of Trade, 2008; Finlayson, 2008). A poll taken days after the budget announcement found $54 \%$ of British Columbians supportive and $40 \%$ opposed to the carbon tax (Environics, 2011).

21. A backlash soon emerged, however, led by Northern and rural communities, who argued that the tax was unfair to their residents because they live in a colder climate and have few, if any, transit options. Although analysis by academics and government indicated that with well-insulated homes and shorter commutes rural residents actually would pay less on average than residents of the urban south, perceptions of unfairness persisted, fuelled by historical political alienation among rural British Columbians (Peet and Harrison, 2012). Northern municipalities passed a series of resolutions condemning the tax in the spring of 2008.

22. Negative reaction was not confined to rural voters, however. A spike in the price of gasoline between the February 2008 budget and the tax's application that July inflamed opposition across the province. With singularly unfortunate timing, the carbon tax took effect the same week that the price of gasoline reached its peak, pushing the price per litre over the symbolic CAD 1.50 mark at Vancouver gas stations. Although the tax in fact accounted for just 2.4 cents of the 40-cent increase experienced by consumers in the spring of 2008, the carbon tax served as a lightning rod for voter discontent with gasoline prices. 
23. A one-time Climate Action Dividend was provided to help British Columbians make investments to reduce their carbon footprints. The mailing of cheques to individuals just as the tax was scheduled to take effect appears to have been an attempt to offset political opposition. If so, the strategy backfired. The Climate Action Dividend was widely depicted as a cynical ploy to buy voters' support, and also may have deflected voters' attention from the significance of larger and permanent cuts in income taxes.

24. The provincial Finance Minister's announcement of her retirement soon after the 2008 budget also may have hindered the government's response to emerging criticisms, since the government lost a popular and seasoned communicator. At the same time, the opposition New Democratic Party (NDP) capitalised on populist opposition with an "Axe the Tax" campaign, unveiled just before the tax was scheduled to take effect. The party's leader argued that the tax was unfair not only to Northerners, but to all "working people who pay the tax, [while] big polluters get a pass" (James, 2008). The claim was misleading at best, since process and fugitive emissions were slated for coverage under a future cap and trade programme (exactly as proposed by the NDP itself), and because firms were subject to the carbon tax on all their fossil fuel purchases, just like households. However, the rhetorical claim that industry was avoiding responsibility reinforced the NDP's claim that their cap-and-trade alternative that would instead "make big polluters pay". The opposition leader also played to voters' concern for rising gasoline prices, invariably referring to the "gas tax" rather than carbon tax.

25. The Axe the Tax campaign shocked the NDP's longstanding allies in the environmental community, not least because the party itself had called for a carbon tax only months before (NDP, 2007). The axe the tax campaign resonated with voters, however. In June 2008, 71\% of British Columbians expected to pay more than they got back through tax cuts (Hogben, 2008), even though with initial tax cuts favouring households, the figure would have been well below 50\%. An August 2008 Angus Reid poll found that $54 \%$ of British Columbians agreed that "putting a price on greenhouse gas emissions is a good idea", but only $19 \%$ thought a carbon tax was the best way to do that. Consistent with the opposition's rhetoric, three quarters believed that government should exclusively target "big polluters." As indicated by Figure 1, support for the carbon tax declined significantly between the date of the announcement in February and the tax's introduction in July 2008. Concurrently, the NDP surged forward in the polls, pulling even with or slightly ahead of the Liberals by the fall (Harrison, 2012).

26. The tax's survival as public opposition emerged owes much to Premier Gordon Campbell's championing of the policy. According to one account, the Premier put his own job on the line, telling anxious caucus colleagues "that if they wanted to get rid of the tax they would have to get rid of him" (Palmer, 2009). The government did make a concession that local governments and school boards (though, curiously, not hospitals and universities) would be rebated their carbon tax payments if they signed the government's Climate Action Charter, which required a commitment to carbon-neutral operations by 2012. In response, 180 of $188 \mathrm{BC}$ municipalities signed the Charter. The concession is easily justified because in order to obtain a refund of their carbon taxes, municipalities would have to commit to paying a comparable price for carbon offsets anyway beginning in 2012. Moreover, municipalities do not get the benefit of corresponding income tax cuts. It is problematic, however, that the mechanism for revenue recycling was not independent of the tax itself, in theory reducing the price incentive from CAD 55 (tax plus offsets) to CAD 25 (offsets only). 
Figure 1. Public reactions to the $B C$ carbon tax

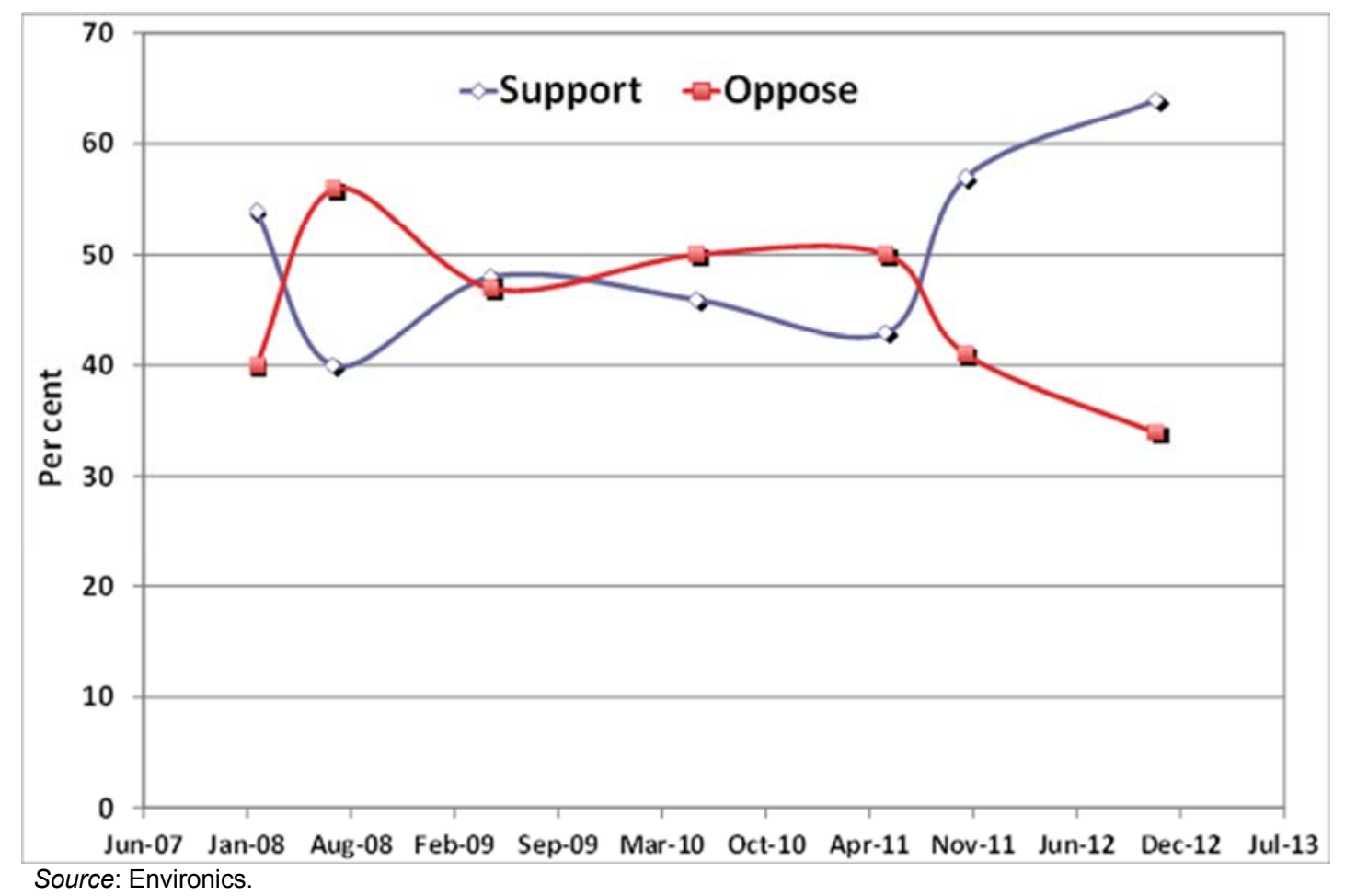

27. Although the Premier could resist pressures from his Liberal colleagues in the short term; over the longer term, the government would have to answer to the electorate. The carbon tax remained unpopular with British Columbians as a provincial election approached in May 2009 (Figure 1). However, voters' attention was deflected from the tax by two critical events. In the latter half of 2008, the price of gasoline fell by CAD 0.50 per litre, and with that the public's attention to fuel prices also declined (Figure 2). Arguably more important, the economy eclipsed all other issues among voters' priorities after the onset of the global recession in the fall of 2008 .

28. The economy was by far the most important issue for voters going into the election. With respect to ability to manage the economy, voters favoured the Liberals over the NDP by roughly $30 \%$. While the NDP platform led with "axe the tax", the Liberal platform was strongly focused on maintaining economic confidence and stability. The Premier seldom mentioned the carbon tax on the campaign trail. However, in its February 2009 budget, the government had introduced a Northern and Rural Homeowner Benefit of CAD 200 per household, which was presumably given greater emphasis by Liberal candidates in rural communities where opposition to the carbon tax remained strongest. Although the tax credit was offered to further offset the tax, the Finance Minister's own staff previously had projected that, because northern and rural residents drive shorter distances, they actually would pay less in carbon taxes than urban dwellers (North Central Municipal Association, 2008). The expenditure thus can only be seen as a ploy to woo back disaffected voters in rural ridings. 
Figure 2. Trends in British Columbians' priorities

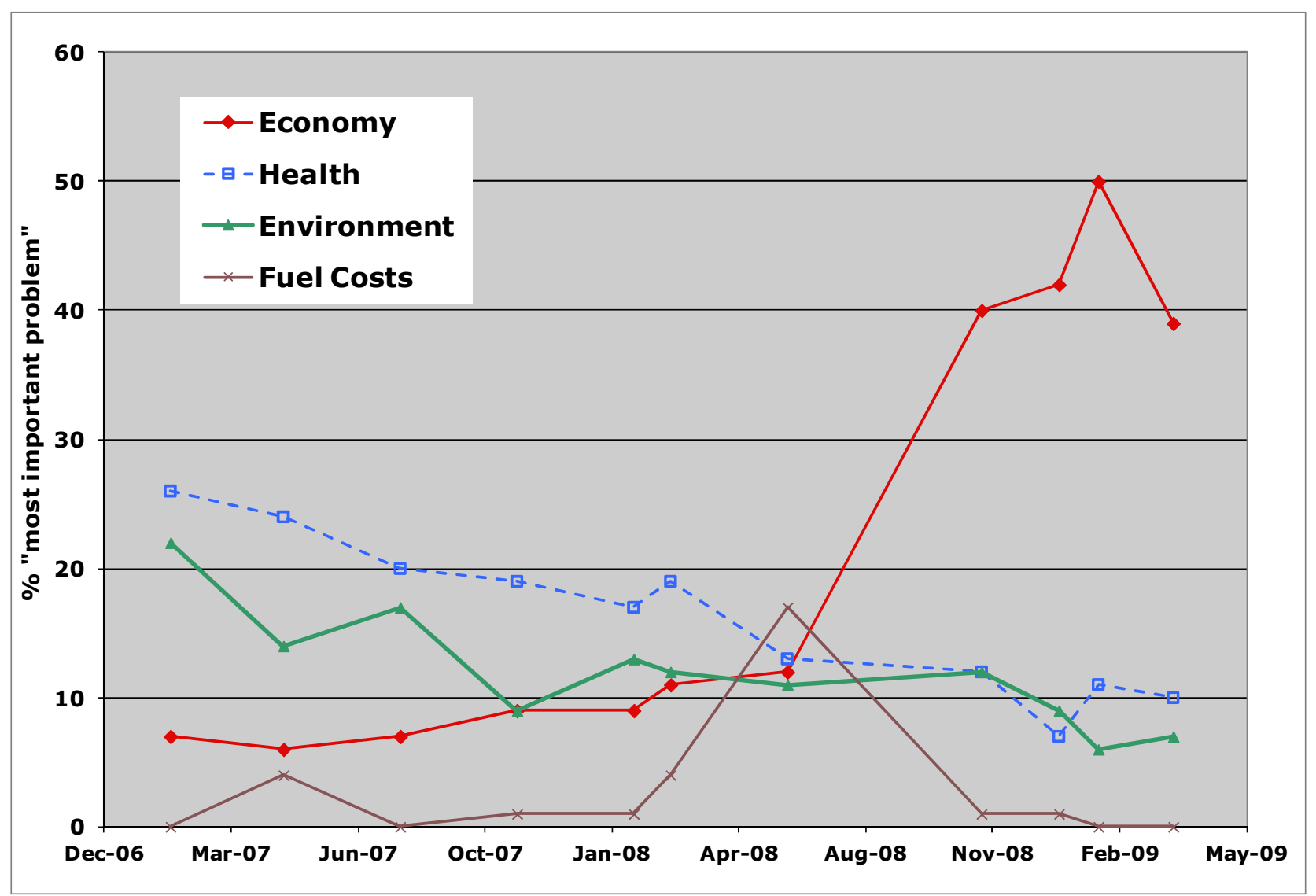

29. The Liberals retained their majority in the 2009 election, though with a reduced number of seats. Given voters' overwhelming attention to the economy, it is unlikely that the carbon tax had much impact on the outcome. To the extent the carbon tax did influence the outcome at the margins, its direction is unclear. The tax's impact depends on how public opinion varied regionally, especially in swing ridings, for which the parties' own detailed polling data are not publicly available. Both parties had staked out positions that risked alienating their historical supporters, environmentalists in the case of the NDP and anti-tax conservatives in the case of the Liberals (Harrison, 2012). Which party was hurt more? The NDP's green credentials were tarnished in the opening days of the campaign by several prominent environmentalists' criticism of the axe the tax platform (though the party's opposition to run-of-river hydro projects and other green proposals undoubtedly reassured many environmental voters). In contrast, disaffected economic conservatives almost certainly returned to the Liberal fold with the onset of the recession. It thus seems mostly likely that at the margin the NDP was hurt more by its opposition to the carbon tax than the Liberals were hurt by their support for it. However, even that outcome was conditional on the complex interplay of party identification, economic concerns, and the carbon tax. In the end, the Liberals were saved by the recession, and so was the carbon tax.

\section{Looking ahead}

30. Five years after its introduction, the politics of BC's carbon tax have changed in several respects. On one hand, the business community, though originally mildly supportive of the tax, has become increasingly anxious. Not only has the tax gradually increased, as planned, from CAD 10 to CAD 30 per tonne, but other North American jurisdictions have failed to follow BC's lead, as many had anticipated in 2008. When $\mathrm{BC}$ introduced its carbon tax, it was in the context of a Canadian federal government 
commitment to a national cap and trade program. With the election of US President Barack Obama just months later, it appeared that Canada's main trading partner also would embrace cap and trade. BC's commitment to the Western Climate Initiative also was matched by the provinces of Ontario, Quebec, and Manitoba, and a growing number of US states. Thereafter, however, Canadian voters rejected a carbon tax in the 2008 national election (Harrison, 2012). The US Congress failed to pass cap-and-trade legislation in 2010, prompting Canada to retreat from its commitment to emissions trading soon thereafter. In turn, all US states except California withdrew from WCI, and among Canadian provinces, only Quebec remains committed to joining California in trading.

31. As $\mathrm{BC}$ became increasingly isolated within North American in its commitment to carbon pricing, the business community raised growing concerns about competitiveness. The $\mathrm{BC}$ Chamber of Commerce cited impacts on greenhouse growers and cement manufacturers, and the threat of leakage via cross-border gasoline purchases (BC Chamber of Commerce, 2012). BC's one refinery argued that it is disadvantaged relative to imported gasoline from Alberta (Schick, 2012). The Business Council of British Columbia called for measures to level the playing field for energy-intensive trade-exposed sectors, such as mining, oil and gas, pulp and paper, and cement (Business Council, 2012). The government's own Jobs and Investment Board of advisors recommended tax adjustments to improve the competitiveness of the natural gas and transportation sectors (Simpson, 2012).

32. A second threat to the carbon tax arose, unexpectedly, from the commitment to carbon-neutral government. Although intended to demonstrate the provincial government's leadership and stimulate BC's carbon market, a consequence of carbon-neutral government has been the transfer of increasingly scarce public sector dollars to the private sector (which, in the absence of an offset requirement, pays a lower total carbon price). Parents were outraged as public school boards struggling to balance their budgets were forced to allocate funds to the Pacific Carbon Trust to subsidise projects undertaken by the likes of the Whistler Resort and Spa and oil and gas company EnCana (Barrett, 2011; Lee, 2011). While the commitment to achieve carbon-neutral government via offsets is conceptually distinct from the carbon tax, which had already been refunded to both school boards and municipalities, the lay public did not always distinguish between two forms of carbon pricing. Controversy concerning carbon-neutral government thus threatened to further undermine public support for the carbon tax. In the face of growing criticism, the provincial government announced the creation of a CAD 5 million fund, equivalent to the value of schools payments' to the Pacific Carbon Trust, to support energy efficiency capital projects in schools.

33. On the other hand, other factors have reinforced the long-term survival of BC's carbon tax. First, and arguably most important, public support for the tax eventually rebounded, as illustrated by Figure 1. In late 2012, with a spring 2013 provincial election just months away, polling revealed that $64 \%$ of British Columbians were either somewhat or strongly in favour of the carbon tax, compared to $34 \%$ somewhat or strongly opposed. It is not clear what accounted for the increase in public support, but one can speculate that consumers may simply have gotten used to or even forgotten the tax. The number of articles in the Vancouver Sun, the province's leading daily, that contain the words "British Columbia" and "carbon tax" published one month either side of the annual July 1 tax adjustment declined from 42 in 2008 to between 7 and 10 in each of the next 4 years. While the emergence of public opposition to the tax in 2008 arguably reflected exaggeration of the costs, particularly in light of concurrent gasoline price increases and low levels of awareness of corresponding income tax cuts, five years later the sky has not fallen and most British Columbians do not give much thought to the carbon tax. Still, the legacy of the "axe the tax" campaign is apparent: when British Columbians are asked what words come to mind in conjunction with the carbon tax, four years later, the three most common (albeit minority) responses still were "unfair," "expensive," and "ineffective" (Horne et al., 2012)

34. The interplay of interest group pressures, electoral opinion, and changes in party leadership have yielded significant shifts in the partisan landscape for the carbon tax. After her party's defeat in the 2009 
election, NDP leader Carol James grudgingly acknowledged that the "carbon tax is here to stay". However, when James resigned as leader the following year, each of the NDP leadership candidates acknowledged in turn that the party's opposition to the carbon tax had been a mistake. The NDP thus came full circle, returning to its earlier support for carbon taxation and seeking to rebuild its coalition of environmental support. The BC Liberal Party also underwent leadership change in 2011, though one that had potential to yield a greater policy shift, both because the carbon tax was so closely allied with the leadership of Gordon Campbell, and because Campbell's successor, as Premier, would be in a position to pursue policy change should they be so inclined. The new Liberal Premier, Christy Clark, did not reverse the scheduled increases through to 2012, but neither did she commit to the fate of the tax thereafter. Trailing in polls to the NDP, and facing growing pressure with respect to the carbon tax from the business community, a resurgent $\mathrm{BC}$ Conservative Party on her right flank, and sceptical members of her own caucus, Clark's government announced in February 2012 that it would undertake a broad-ranging review of the carbon tax. At the same time, the government announced a first concession to business on competitiveness grounds, in the form of "one-time" compensation of CAD 7.6 million to greenhouse growers.

35. A final factor contributing to the long-term survival of the $\mathrm{BC}$ carbon tax was the provincial government's growing reliance on the tax revenues. Regardless of whether the original tax was revenueneutral or not, five years later elimination of the tax would leave a $3 \%$ hole in the provincial budget that, in an era of fiscal restraint, would have to be filled with increases to other taxes - thus risking renewed public ire just as opposition to the carbon tax had subsided. The need to balance the budget may explain why the Liberal Party overwhelmingly voted in support of maintaining the tax at their October 2012 convention (MacLeod, 2012). Similarly, the Chamber of Commerce and Business Council called only for a freeze on further increases in the 2013 budget, despite oft-cited concerns from its members about impacts on competitiveness (Business Council, 2012; Winter, 2012).

36. The carbon tax review generated over 2000 individual submissions and 100 more from business and non-governmental organizations. Despite speculation that the outcome would be significant reforms or even elimination of the tax, the review ended with a whimper, rather than a bang. The 2013 budget essentially committed to the status quo, with no change to the level of the tax at CAD 30 per tonne, no extension of coverage to fugitive or process emissions, no retreat from revenue neutrality, and only minimal concessions to business (British Columbia, 2013). The government committed to return $80 \%$ of tax revenues to greenhouse vegetable and flower growers, and to exempt fuels used in farm operations. It is unfortunate that in both cases the form of the concessions undermined the price signal, which could have been maintained by recycling lump sums (e.g., based on sectoral averages) rather than waiving the tax. However, while assuaging a politically influential rural constituency for the BC Liberals (and one for which the BC Conservatives' call to eliminate the tax undoubtedly resonated), the two commitments together account for just $1 \%$ of combustion emissions and carbon tax revenues.

37. The carbon tax was again prominent in the May 2013 election, but in a reversal of the politics of the 2009 election. In contrast to the "axe the tax" campaign four years earlier, the NDP called for extension of the tax to vented emissions from the natural gas industry (though not for an increase in the tax rate nor extension of the tax to process or fugitive emissions). The Liberals promised to freeze the level at CAD 30 per tonne for five years, stressing that they would "make life more affordable for British Columbians" in contrast to the NDP's alleged plans to increase the tax (Bailey, 2013a). At the same time, however, the Liberals proposed to create a "Prosperity Fund" via a new tax on liquefied natural gas exports, which would generate much greater revenues from the industry than the NDP's proposed extension to the gas industry's vented emissions. On election day, the Liberals were returned to government in a stunning come-from-behind victory, thus promising survival of the tax at its CAD 30 per tonne for the foreseeable future. Buoyed by victory and supportive polls, the Premier has advanced the example of BC's carbon tax in discussions with other provincial governments (Bailey, 2013b). 


\section{Evaluation of the $\mathrm{BC}$ carbon tax}

38. It is always challenging to evaluate the impact of a single policy given concurrent impacts of other public policies and changes in the economy. That is especially true in the case of the $\mathrm{BC}$ carbon tax, which was accompanied by a slate of other new climate change mitigation policies and which took effect just months before a global recession. Several years of data are needed to unpack concurrent effects, and as such studies of the impact of the carbon tax are only beginning to emerge.

39. Reports by the provincial government and academic analyses both note that BC's consumption of fossil fuels declined by significantly more than the national average between 2008 and 2012, with the sole exception of aviation fuel, which is the one fossil fuel largely exempt from the tax (British Columbia, 2012c; Elgie and McClay, 2013). Figure 3 reveals the divergence between trends of petroleum consumption in British Columbia and the rest of Canada. In the first four years of the carbon tax, BC's per capita consumption decreased by $17.4 \%$, while that of the rest of Canada increased by $1.5 \%$.

Figure 3. Sales of petroleum fuels subject to British Columbia's carbon tax 2000-2012

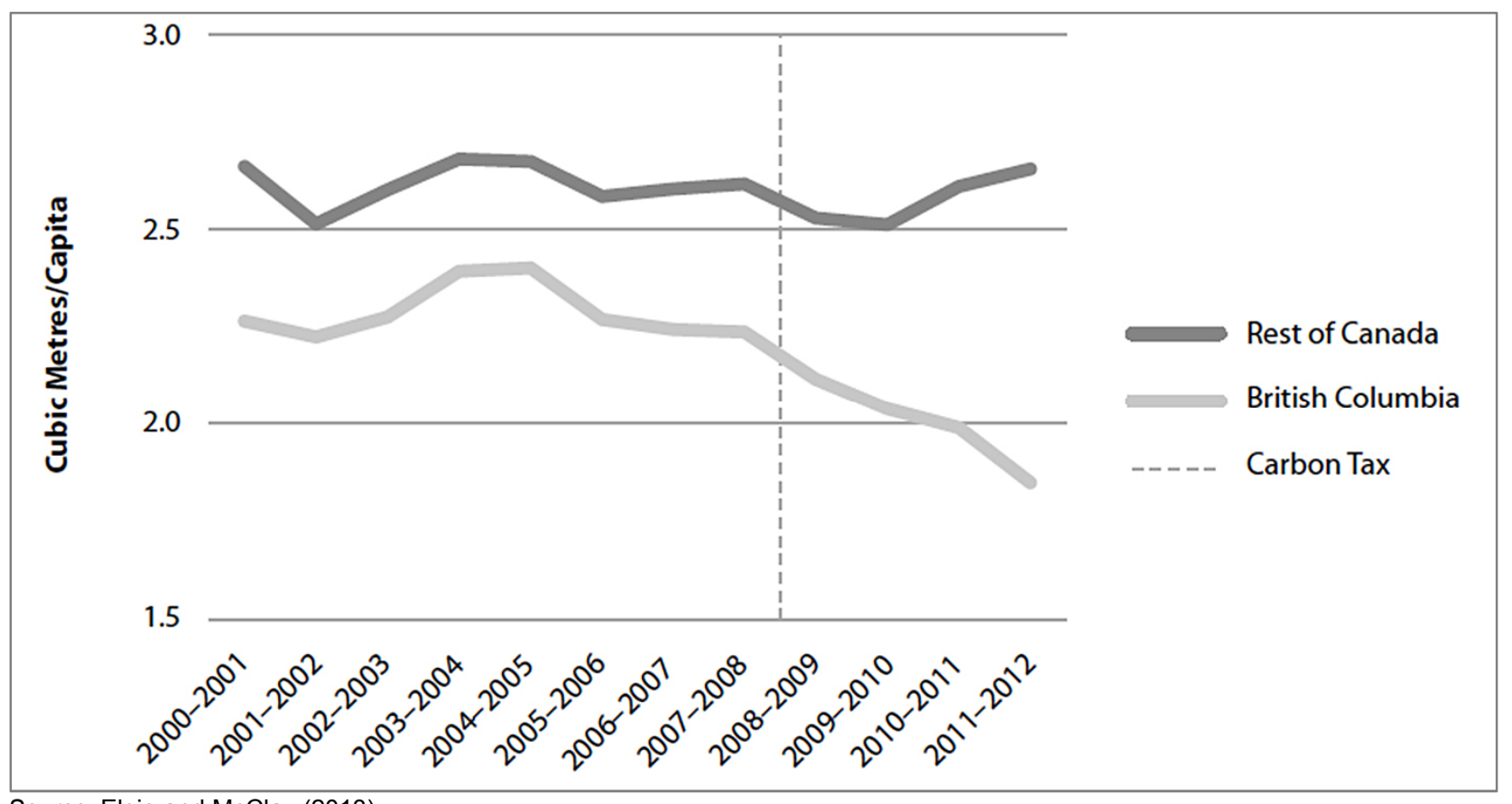

Source: Elgie and McClay (2013).

40. Of course, broad trends offer only circumstantial evidence that the BC carbon tax is working. Divergence among provinces in fossil fuel consumption may be explained by economic restructuring or the impact of other public policies unrelated to the carbon tax. In that regard, however, Rivers and Schaufele (2012), compared BC's and other provinces' monthly gasoline consumption before and after the carbon tax, statistically controlling for a variety of other factors, including population, residents' after-tax income, gasoline prices, other provincial policies, and the fraction of compact vehicles in the provincial stock. At a carbon tax of CAD 25 per tonne in 2011, the authors found a $12.5 \%$ reduction in gasoline consumption due to the tax, compared to an anticipated $1.8 \%$ reduction from a comparable price increase due to market forces. They attribute the exaggerated impact to the salience of the carbon tax to consumers. In effect, the same visibility that provoked a political backlash may also have prompted greater efforts to conserve energy. Consistent with this salience effect, a study of the impact of the carbon tax on local governments founds that local officials include the carbon tax (in addition to the price of offsets) in their economic 
analysis of capital projects, even though municipalities in fact receive a full rebate of their carbon tax payments (Pembina, 2012). No independent analyses have been published to date concerning household responses to the carbon tax.

41. On the economic side, GDP growth in $\mathrm{BC}$ in the first four years of the carbon tax was virtually identical to the national average (Elgie and McClay, 2013). BC has seen twice the national rate of investment in clean energy and hybrid vehicles, and now enjoys the lowest corporate and individual income taxes in Canada (British Columbia, 2012c). However, Lee (2011) reports that although the impact of the tax on lower-income households was initially offset fully by tax cuts and the low-income tax credit, the $15 \%$ increase over time in the low-income tax credit has not kept pace with tripling of the tax from CAD 10 to CAD 30 per tonne. Lee concludes that the net impact of the tax is small but regressive, particularly when one considers the incidence of corporate tax cuts, which would tend to disproportionately benefit wealthy investors.

42. The impact of the carbon tax on business competitiveness is of particularly interest in light of the BC tax's isolation within North America. In the section of the 2013 budget reporting on the carbon tax review, the provincial government reported that its own, "Economic analysis conducted for the carbon tax review indicates that BC's carbon tax has had, and will continue to have, a small negative impact on gross domestic product (GDP) in the province. ... Industries with high emissions intensities, such as cement production, petroleum refining, oil and gas extraction and some other manufacturing subsectors, are most impacted" (British Columbia, 2013, 59). The province has not released those analyses, and with the exception of the agricultural sector, the province apparently did not consider the impacts sufficient to justify tax relief. The one academic study to date of the impact of the $\mathrm{BC}$ carbon tax on business competitiveness focused on the agricultural sector, but found that the sector is neither particularly carbon intensive nor trade-exposed relative to other sectors in BC. After controlling for factors such as geography and weather, Rivers and Schaufele (2013) report a small positive impact of the carbon tax on net agricultural exports, though a minor but statistically insignificant negative impact was found for vegetable and flower exports. The authors conclude that, "the exemptions from the carbon tax for the greenhouse sector, which were justified primarily based on concerns over international competitiveness, are likely unnecessary".

\section{Conclusions}

43. The emergence of a carbon tax in British Columbia reflected a perfect storm of political conditions for carbon taxation: availability of untapped hydro potential, a surge in public concern for climate change, a right-wing government with the trust of the business community (a "Nixon goes to China" effect), and a committed leader with the institutional capacity to pursue his "good policy" preferences. Even then, the carbon tax soon elicited strong opposition, reflecting a combination of public misunderstanding of environmental taxation, consumers' disproportionate focus on the tax to the exclusion of tax cuts, and historical alienation of rural voters, all of which was fuelled by opportunistic political opposition. In the face of strong public disapproval, the carbon tax was "saved" by the chance timing of the global recession, which deflected public attention away from the tax to the economy, an issue that favoured the governing party. With respect to both the carbon tax's adoption and its survival, the outcome is overdetermined. One cannot know whether the tax would have been adopted with one or more conditions absent. However, comparison to other Canadian provinces suggests that heightened public concern, supportive political institutions, and untapped hydropower (as in Manitoba and Quebec) alone were not sufficient.

44. Though its launch was rocky, the BC carbon tax has enjoyed smoother sailing as time has passed. The $\mathrm{BC}$ experience suggests that the political economy of an established carbon tax is quite different from that of a new one. As public attention subsides and the government becomes increasingly reliant on carbon 
tax revenues, it becomes easier to keep than abolish an existing carbon tax. That said, with British Columbia increasingly isolated in its commitment to carbon pricing, the question remains whether the province will extend its initial concessions to agricultural producers to other sectors claiming impacts of the tax on competitiveness. If it does, it is critical that concessions be based on sound analysis and clear principles, rather than strength of political objections, and carefully designed to maintain the carbon price signal. Experience with concessions granted by the province to local governments, rural voters, and farmers to date provide cause for concern. 
ENV/WKP(2013)10

\section{REFERENCES}

Bailey, Ian (2013a), "B.C.'s Clark Vows to Freeze Carbon Tax for Five Years”, Globe and Mail, 4 April.

Bailey, Ian (2013b), "B.C. Plans for Promote Carbon Taxes, Among Other Green Initiatives", Globe and Mail, 23 June.

Baldwin, R. (2008), "Regulation lite: The rise of emissions trading", Regulation and Governance, 2(2), pp. 193-215.

Barrett, Tom (2011), "Why the Pacific Carbon Trust Draws Political Heat", TheTyee.ca, 5 December.

BC Chamber of Commerce (2012), Policy and Positions Manual, 2012-13.

Belfry, K. (2010), The Third Man: Investor Influence on Business Preferences for Climate Change Policy Instruments in Canada, Paper presented at the Annual Meeting of the Canadian Political Science Association, June.

British Columbia (2012a), British Columbia Greenhouse Gas Inventory Report 2010.

British Columbia (2012b), Budget and Fiscal Plan, 2012/13-2014/15.

British Columbia (2012c), Making Progress on BC's Climate Action Plan.

British Columbia (2013), Budget and Fiscal Plan, 2013/14-2015/16.

Business Council of British Columbia (2012), Submission on the Provincial Carbon Tax.

Ciocirlan, C.E. and B. Yandle (2003), "The political economy of green taxation in OECD countries", European Journal of Law and Economics, 15, pp. 203-18.

David Suzuki Foundation, (2008), "B.C. environmental groups applaud carbon tax legislation. [Press Release], 28 April. Retrieved from www.davidsuzuki.org/media/news/2008/04/bc-environmentalgroups-applaud-carbon-tax-legislation/.

Davis, Steven J., Glen P. Peters and Ken Caldeira (2011), "The Supply Chain of $\mathrm{CO}_{2}$ Emissions", PNAS, 108,45 , pp. 18554-9.

Elgie, Stewart and Jessica McClay (2013), "BC's Carbon Tax is Working Well After Four Years

(Attention Ottawa)", Canadian Public Policy, XXXIX, pp. S1-S10.

Environics (2011), "Canadians continue to support strong support for actions to address climate change", 30 November.

Finlayson, J. (2008), “BC's carbon tax doesn't let polluters' off”, The Vancouver Sun, p. A9, 6 August.

Green, D. (2007), "Why 70 economists urge BC carbon tax", The Tyee. Retrieved from http://thetyee.ca/Views/2007/11/01/CarbonTax/, 1 November.

Harrison, Kathryn (2010), "The Comparative Politics of Carbon Taxation”, Annual Review of Law and Society, 26, pp. 1-23.

Harrison, Kathryn (2012), "A Tale of Two Taxes: The Fate of Environmental Tax Reform in Canada", Review of Policy Research, 29, pp. 383-407.

Harrison, Kathryn, 2013. "Federalism and Climate Policy Innovation: A Critical Reassessment", Canadian Public Policy, XXXIX, pp. S95-S108. 
Hogben, D. (2008), "Most don't like carbon tax, poll finds", The Vancouver Sun, p. B1, 30 July.

Horne, Matt, Kevin Sauvé and Tom Pedersen (2012), British Columbians' Perspectives on Global Warming and the Carbon Tax, Pembina Institute and Pacific Institute for Climate Solutions Vancouver.

Jaccard, Mark (2007), "The second inconvenient truth: We must tax greenhouse gases or they will keep rising", The Vancouver Sun, p. A15, 24 October.

James, Carol (2008), "Campbell makes the wrong choice", The Vancouver Sun, p. A13.

Kahneman, D., J.L. Knetsch and R.H. Thaler (1991), "Anomalies: The endowment effect, loss aversion, and status quo bias", The Journal of Economic Perspectives, 5, 1, pp. 193-206.

Lee, Marc (2011), Fair and Effective Carbon Pricing: Lessons from British Columbia, Vancouver, Canadian Centre for Policy Alternatives.

MacLeod, Andrew (2012), "BC Liberals Vote to Support Keeping Carbon Tax", TheTyee.ca, 27 October.

Mather, C., N. Olewiler \& S. Elgie (2007), "BC's carbon tax shift is smart public policy”, The Globe and Mail, p. A21, 29 November.

Natural Resources Canada (2012), Fuel Focus: 2011 Annual Review. Accessed at www.nrcan.gc.ca/energy/sources/petroleum-crude-prices/gazoline-reports/2012-01-13/2080\#supsup.

NDP Standing Committee on the Environment for an Ecologically and Economically Sustainable Future, (2007), Sustainable BC, 17 November.

North Central Municipal Association (2008). Provincial Response to NCMA Resolutions. 7 May. Accessed at http://ncma.enorthernbc.com/publications/422A191AA69E485DB4EDF24DAB0184FE.pdf.

Palmer, Vaughn (2009), "Campbell's reviled carbon tax paid off for him in the end", The Vancouver Sun, A3, 14 May.

Peet, Chelsea and Kathryn Harrison (2012), "Historical Legacies and Policy Reform: Diverse Regional Reactions to British Columbia's Carbon Tax," BC Studies, 173, pp. 95-120.

Pembina Institute (2012), Case studies at www.pembina.org/pub/2373.

Rhodes, Ekatarina and Mark Jaccard, (2013), “A Tale of Two Climate Policies: Political-Economy of British Columbia's Carbon Tax and Clean Energy Standard”, Canadian Public Policy, XXXIX, pp. S37-S51.

Rivers, Nicholas and Brandon Schaufele (2012), Salience of Carbon Taxes in the Gasoline Market, http://papers.ssrn.com/sol3/papers.cfm?abstract_id=2131468.

Rivers, Nicholas and Brandon Schaufele (2013), Carbon Taxes, Agricultural Competitiveness and Trade, http://papers.ssrn.com/sol3/papers.cfm?abstract_id=2310566.

Simpson, Scott (2012), "BC should revisit carbon tax, attract angel investors", Vancouver Sun, 7 September, F1.

Schick, Dave (2012), Testimony to the Select Standing Committee on Finance and Government Services, Province of British Columbia, 1 October.

Vancouver Board of Trade (2008), Board of Trade grades "smart carbon tax budget" with an 'A' report card, 19 February, Retrieved from www.boardoftrade.com/publicationsresources/mediacentre/media-releases/MediaReleases2008/MediaRelease19Feb2008.aspx

Winter, John (2012), Testimony to the Select Standing Committee on Finance and Government Services, Province of British Columbia, 1 October. 